\title{
Artigo
}

\section{A vez dos leitores: o retornar do desastre}

\author{
Pedro Augusto Papini* \\ Tania Mara Galli Fonseca [D \\ Universidade Federal do Rio Grande do Sul, Porto Alegre, RS, Brasil
}

Resumo: Neste artigo levantamos as problemáticas sobre uma função ética da criação e da imaginação diante dos restos do desastre. Objetivamos percorrer articulações teóricas que enredam as reflexões sobre os conceitos de testemunho e de lugar de fala, colocando-os em perspectiva no que concerne a remontar ou recontar o tempo sofrido. Para isso, localizamos vincos aporéticos nesses conceitos, os quais insistem na exploração do lugar da leitura e do leitor diante de um tempo paradoxal que se coloca também como produção e invenção do tempo presente. Exploramos o caminho das articulações entre tempo, imaginação, imagem, catástrofe e responsabilidade, tendo como resultado a ampliação de um ponto de vista ético pelo ato de criação, que coloca a leitura como produtora de memória.

Palavras-chave: escuta, memória, história, imagem, imaginação.

"Imagens inapreensíveis, imagens que continham em si toda a orfandade do mundo".

(Bolaño, 2010, p. 206)

\section{Mesas para recolher os pedaços do mundo}

Este texto é uma exposição e uma abertura aos problemas da criação e da verdade no relato da catástrofe. As construções teóricas funcionam como objetos em uma mesa de orientação para o retorno do desastre. Aqui, a palavra "mesa" guarda uma gama de sentidos confluentes a espaço de compartilhar e de unir elementos móveis e heterogêneos. Pode-se, ainda, pensá-la como plano para organizar o caos, possibilitando tanto o ex-por quanto um dis-por de elementos que, uma vez reunidos de certo modo, formulam sentido à transmissão da experiência do trauma (Deleuze \& Guattari, 2010).

Didi-Huberman (2018a) lembra que Mensa, em latim, inicialmente designava um gênero de doce que se dividia em pedaços, dispostos como oferenda para os deuses e como comida consumível sobre um campo operatório que logo se apropriou de seu nome. Mesa de oferenda, de cozinha, de dissecação ou de montagem. O filósofo opõe a noção de mesa à noção de quadro - tão próximas no vocabulário francês: table e tableau. O quadro nos traz algo pronto, acabado - um quadro, penduramos nos frisos de um museu como uma obra, um resultado em que tudo foi decidido. Uma mesa, utilizamos para novos banquetes, novas configurações, funcionando como prancha ou plano espacial no qual elementos heterogêneos assumem posição, configurando um arranjo ou agenciamento de corpos em relação de contágio. Em uma mesa, tudo poderá sempre se repetir, embora seja necessário assinalar que as repetições

\footnotetext{
* Endereço para correspondência: pedroaugustopapini@gmail.com
}

já virão desassemelhadas em relação à origem. Esse fato nos leva a reconhecer cada repetição como expressão de uma variação. Claro que podemos colocar um quadro sobre uma mesa, mas podemos colocar outros quadros ao lado daquele primeiro, e tudo pode mudar neste quadro anterior.

A mesa se apresenta como campo operatório do díspar e do móvel, do heterogêneo e do aberto. A mesa é o suporte de um trabalho sempre a retomar, a modificar. $\mathrm{O}$ que enfocamos em nosso texto nos permite pensar uma mesa de montagem como o espaço onde se constroem legibilidades, como o canteiro de uma obra se fazendo e refazendo, como lugar de coabitação entre destruição e construção, morte e vida, o que foi e o que será. Como a prancha estirada do trampolim de alguma piscina, a mesalaboratório da emergência de legibilidades se mostra como lugar de passagem, de salto e de voo suspenso entre dois abismos: o das alturas e o das profundidades, lugar de condução incerta e não predeterminada, lugar de escolhas e de perícia, de arte e invenção. Definida como um entretempos e entre-espaços, a mesa opera como um fundo neutro diante do que pode vir a ser ligado e des-ligado em sua superfície. Esta, por sua vez, se torna encantada e mutante pelos efeitos que dão a ver e a ler a partir dos acontecimentos suscitados pelos gestos de uma multidão de autores. Não se trata, pois, de auferir sentido a partir de uma individualidade, de um único autor ou sujeito. No plano comensal do banquete das possíveis legibilidades, todo um meio associado das pequenas percepções colabora, torna-se cúmplice e mesmo invasor daquilo que virá como futuro possível ou devir.

\section{Depois do desastre: trabalhos aporéticos}

Situamo-nos diante do complexo trabalho de rememoração da catástrofe. Nossa travessia se dá por pontes quebradas, pinguelas frágeis em direção aos 
restos e rastros pouco iluminados ou até mesmo sem qualquer clareza que operam como pontas visíveis de icebergs diante de nosso olhar ou tateio. Percorremos um palimpsesto em cujas camadas temporais encontram-se gravados, em situação de quase apagamento, traços e marcas de situações passadas, já detentoras do que se poderia chamar de memórias passíveis, em maior ou menor grau, de vir a ser rememoradas e salvas de seu afundamento e perdição na lama das matérias em depósito e silêncio no grande passado do esquecimento. Nossas escolhas conceituais centralizam-se nos gestos de instaurar condições de existência ao que subsiste em situação mínima e virtual, buscando enunciar o desastre pelas aporias do impossível. Esses são perigos da travessia das imagens do desastre e provações a que estão expostas as remontagens do tempo sofrido; tal fato nos coloca diante do desafio ético sobre ler o desastre, que terá a ver com a dimensão de prova e de provação do arquivo. É o desafio ético de abrir os olhos sobre a história.

Uma imagem de leitor sobrevive às semelhanças e dissemelhanças dos conceitos abordados aqui. Essa imagem diz respeito a um tempo, ou seja, a uma "vez", um momento em que o passado encontra o presente como um relâmpago que forma um clarão efêmero. Esse momento também é o encontro de um autor e de um leitor, mas de um autor que não está mais ali senão pelos seus restos. Autores que contam sobre desastres nos sugerem explorar algo das astúcias epistemológicas dos conceitos de testemunho e de lugar de fala.

A questão da semelhança será sustentada pelo pensamento de Blanchot e Didi-Huberman quando pensam na semelhança das imagens. Munidos desse aparato conceitual, consideramos possível pensar no leitor como um sobrevivente: o sobrevivente como semelhante do morto, o leitor como semelhante do autor. Veremos como a vez dos leitores se faz, igualmente, como vez de um atlântico trabalho de imaginação. São um esforço e um tormento que ampliam pontos de vista pelo do ato de criação e colocam a leitura como produtora de memória.

Se tomarmos a premissa de que só podemos falar sobre o desastre ao retornar dele, ou ao sobreviver a ele, reconhecemos, então, estarmos todos depois do desastre; ou seja, situados como seus leitores. É assim que falar do desastre se torna, inexoravelmente, falar um tempo que tem duas pontas: a ponta de um passado passado-passado e, a outra, de uma duração, ou seja, daquilo que ainda insiste mesmo em sua condição de resto a pedir passagem. É um tempo paradoxal que indica que, se for preciso uma orientação para retornar do desastre, esta deveria ser a de uma construção epistemológica que enlaça o depois como a própria insistência para reorientar a remontagem do passado. Testemunho e lugar de fala organizam o que poderíamos chamar de vez dos leitores, estes que vêm num só depois, só depois da escrita (ou só depois do desastre), mas que constituem a própria escrita e a sobrevivência do desastre; e, num trabalho coletivo ou de um povo (ou mesmo de um povo que falta), constroem uma hora da legibilidade.
Dos vincos aporéticos entre o testemunho e o lugar de fala, restará um leitor apesar de tudo, a partir de algo que o próprio desastre inflige sobre suas imagens e sobre o trabalho de lê-las. O trabalho de ler o desastre também implica no trabalho de escrevê-lo. Daí as explorações sobre as semelhanças e dissemelhanças entre autor e leitor, ou o leitor como produtor de presente e criador de passado.

\section{Vezes e vozes apesar de tudo}

Existem, pelos menos, duas tradições para pensar o testemunho no que concerne a sua dimensão antropológica de memória da catástrofe: a zeugnis e o testimonio. Ambas deixam-se traduzir do alemão e do espanhol para o português por testemunho, mas a permanência da intraduzibilidade dos termos salva a ancoragem de tempo e de espaço que as envelopa singularmente.

Para conhecer essas vertentes do testemunho é importante pensar as raízes etimológicas distintas da palavra testemunho (desta vez, do latim) para localizar a posição que ocupa a testemunha da violência no momento de seu relato. Testis e superstes: a primeira se refere àquele que presenciou um evento e pode, por isso, prestar seu testemunho do ocorrido; já superstes diz respeito àquele que atravessou o evento, ou seja, que estava implicado diretamente no que é narrado. Alguns autores gostam de pensar em Homero como um primeiro superstes da tradição. Mas o conceito de testemunho pouco tem a ver com Homero de fato; o exemplo do herói grego soa mais como uma ideia para reconhecer o superstes como aquele que vara completamente o evento e narra a história. No entanto não há nada de heroico nas teorias do testemunho. $\mathrm{O}$ sumo que faz as reflexões sobre o testemunho, ou mesmo o que vai fazer que importe diferenciar testis e superstes, são as catástrofes do século XX - das quais não restaram heróis, mas sobreviventes.

Agamben marca, a partir de Primo Levi, que não há verdadeira testemunha no caso da Shoah, pois quem realmente atravessou o evento até o fim seriam os que não retornaram, "os que fitaram a Górgona" - estas seriam as "testemunhas integrais" (Agamben, 2013). Aqui, no entanto, leva-se em conta a pessoa que testemunha em sua dimensão de sobrevivente. Desde aí, o filósofo, e mesmo Primo Levi, marcam a precariedade essencial do testemunho que se afirma sob o signo de seu colapso e de sua impossibilidade. O que resta de Auschwitz, para Agamben, é a própria ineficácia em dizer. O sobrevivente da Shoah pode ser um superstes, mas, ao mesmo tempo, testis dos afogados. Estará sempre numa posição de precariedade do relato. E, ainda, terá que narrar, apesar de tudo. Pois, se os que fitaram a Górgona não podem falar, os testemunhos que restam funcionam como escudos de Perseu para fitar o horror.

No mito grego sobre Perseu, o rosto da Medusa Górgona, com seus enormes dentes e sua língua protuberante, era tão horrível que um mero olhar sobre ela transformava os homens e as bestas em pedra. Perseu utiliza 
seu escudo polido para ver o rosto da Medusa sem olhá-lo diretamente. Seligmann-Silva (2008) coloca a literatura e a arte como artifício qual um escudo de Perseu para fitar o que seria infitável ou representar o irrepresentável no que concerne ao desastre. Podemos pensar também em uma realidade que se reflete numa poça de água, embora uma rajada de vento possa turvar a superfície e, com ela, a imagem. Essa turvação é o próprio efeito do tempo que mexe a imagem; na situação testemunhal, o passado é o tempo presente, como em espelhos que não envelhecem.

Primo Levi (1990) nos lembra de que os que testemunharam foram apenas os que justamente conseguiram se manter a certa distância do evento: "a história do Lager foi escrita quase exclusivamente por aqueles que, como eu próprio, não tatearam seu fundo" (p. 5). Pois, diz ele, "quem o fez não voltou, ou então sua capacidade de observação ficou paralisada pelo sofrimento e pela incompreensão" (p. 5). Resta, de certo modo, imaginar; mas é possível imaginar? Robert Antelme, em A espécie humana, nos fala dos campos de concentração aos quais sobreviveu como "uma realidade que parece ultrapassar a imaginação" (Antelme citado por Seligmann-Silva, 2008, p. 70).

Dito isso, a impossibilidade que assombra o testemunho diz respeito não apenas ao fato de quem fala não ter atravessado completamente o evento no sentido de ter sobrevivido, mas, ainda, do problema constitutivo em narrar aquilo que excede as referências do narrável. Essa direção anima pesquisas que buscam trabalhar com relatos e memórias de catástrofes, como SeligmannSilva (2013), Oliveira (2013), Rafaela Scardino (2013), Fonseca, Cardoso Filho e Resende (2014), e Fonseca, Caimi, Costa e Sousa (2018). Narrar aquilo que excede as referências do narrável assemelha-se a ver aquilo que excede as referências do visível, já que esse problema se repete mesmo no caso de fotografias. Uma questão ética da imaginação e das imagens, como imagens que restam, nos instiga, pois, a pesquisar o que podemos colher da relação entre imaginação e história.

Neste debate, Didi-Huberman (2012) coloca-se contra todo e qualquer inimaginável e nos fala de "imaginar apesar de tudo" (p. 227, grifo nosso) ao construir uma legibilidade para certas imagens dos campos de concentração. O filósofo francês, situando-se na discussão sobre quatro determinadas fotografias tiradas clandestinamente por prisioneiros de Auschwitz em agosto de 1944, nos lembra de que uma ética das imagens deve ter em conta uma situação permanentemente clivada. Por isso, a expressão "apesar de tudo" denota uma dilaceração: enquanto o "tudo" nos reenvia para o poder de condições históricas para as quais ainda não conseguimos encontrar respostas, o "apesar de" resiste a esse poder unicamente pela potência heurística do singular.

As imagens de 1944 existiram devido a um complexo trabalho, mas elas delegam ao futuro outro trabalho: o de imaginar o que ali aconteceu. Neste caso, a imaginação funciona como imagem-escudo
(Didi-Huberman, 2012) que, na mesma medida que nos protege, nos ajuda a encarar, a enfrentar. Essa é uma posição em relação à imagem que não serve para cobrir a verdadeira face do passado: serve para encará-lo, para enfrentá-lo, inquiri-lo, até mesmo para cortar sua cabeça.

Tais reflexões sobre imaginação, possibilidades da imagem e narrabilidade são frutos da proliferação da necessidade de narrar as atrocidades envolvidas nos campos de concentração nazistas na Segunda Guerra, cuja aporia maior será a constante do impossível de representar, mas o imprescindível de fazê-lo. Isso gera uma série de melindres e constitui a posição de DidiHuberman sobre imaginar apesar de tudo. Pois, como afirma Agamben (2013), no caso do testemunho, será preciso acolher essa ineficácia na língua - caso se queira acolher algo que reste de Auschwitz.

Portanto é importante marcar que a testemunha na tradição da zeugnis ocupa um lugar não tanto no acontecimento em seus desdobramentos jurídicos, mas antes no que diz respeito a uma nova normatividade ética e a uma ética da representação. "O sobrevivente não traz apenas o testemunho do ocorrido, interposto do verdadeiro/falso da cena tribunal; seu testemunho implica uma nova ontologia do arquivo e uma nova epistemologia da história" (Brito, 2013, p. 62).

Essa nova ontologia do arquivo e epistemologia da história atende a uma necessidade de contornar aquilo que se coloca como inenarrável, fazendo com que as bordas da prova e da provação sejam estendidas a ponto de virem a ser incluídas uma na outra sem perder suas diferenças. Enquanto a prova quer estabelecer os fatos na sua visibilidade imediata e atemporal, a provação diz respeito a estabelecer o difícil estado de tempo dessas experiências - que é onde se coloca a exigência do viés literário do testemunho. $\mathrm{Se}$, de um lado, o protocolo jurídico quer estabelecer os fatos com suas provas, a escrita do testemunho procura figurar o acontecimento em sua temporalidade, que é a da provação. Para Didi-Huberman (2018b), "só se pode dar às imagens dos campos sua 'legibilidade apesar de tudo' seguindo uma ética da escritura, segundo a qual, diante do inominável, é preciso, decididamente, continuar, isto é, temporalizar, sem descanso" (p. 33).

O historiador da arte evoca um relato de Primo Levi em que este conta que, no momento da abertura dos campos de concentração, quando os sobreviventes tentavam já contar o que aconteceu ali para os soldados, "a princípio, o soldado escuta, mas como [os sobreviventes] falam sem parar, em pouco tempo o soldado já não presta mais atenção" (Didi-Huberman, 2018b, p. 37). Aí o filósofo interpreta que aqueles que acabavam de abrir os olhos para as provas (o que Levi nomeia de "mortos no chão, em meio ao lixo, e sujeitos passeando ao redor"), já fechavam os olhos sobre a provação, isto é, "que ainda não conseguiam, por falta de tempo, encontrar uma legibilidade para a experiência daqueles que, no entanto, estavam sob seus olhos, aqueles que, em vão, tentavam contar-lhes a experiência" (DidiHuberman, 2018b, p. 37). 
O testemunho da Shoah passa a tensionar as relações entre imaginação e história, e isso instala uma crise nos índices de representabilidade do ocorrido. Aqui se estende um debate antagônico sobre o inimaginável e o lugar da imaginação no relato da catástrofe. Segundo Seligmann-Silva (2008), a imaginação se apresenta como meio para enfrentar essa crise do testemunho, que se origina na própria incapacidade da vítima testemunhar, a incapacidade de se imaginar os campos - o elemento inverossímil daquela realidade ao lado da imperativa necessidade de testemunhar como meio de sobrevivência. "Aqui a literatura é chamada diante do trauma para prestarlhe serviço" (Seligmann-Silva, 2008, p. 70) naquilo que concerne à provação. Acrescentamos que não somente a literatura, mas as imagens que - por sua vez, segundo o apoio de Maurice Blanchot (2011) a ser explorado no último item antes da conclusão deste escrito - têm a ver com o próprio espaço literário, que aí então terá a ver com o tempo e com a semelhança - semelhança do autor e do leitor da responsabilidade do tempo que compartilham.

A vertente da tradição testemunhal do testimonio, ou testemunho hispano-americano, sustenta esse debate sobre os impasses constitutivos do narrar o tempo sofrido. No entanto ela se fia num contexto específico cuja referência decisiva não é mais a Shoah, mas as ditaduras assassinas perpetradas na América Latina durante a Guerra Fria. Pensar "neste corpo, nesta dor, nesta fome" (Penna, 2013) terá como resultado uma ênfase importante da literatura de testimonio na ideia de que a literatura possa funcionar como um contra-arquivo; que possa funcionar como uma versão da história em detrimento do silêncio e do segredo da violência que pretendem denunciar - inclusive no campo jurídico. Daí termos hoje, diante de nós, uma proliferação de testemunhos em primeira pessoa, frontalmente opostos à versão oficialesca dos regimes ditatoriais. Segundo Brito (2013), "na memória do Testimonio muitos relatos se afastam do conceito estrito de 'literatura' por buscar o restabelecimento da verdade da perseguição ditatorial" (p. 72). Trata-se de criar ("criar" como se cria um filho?) a palavra, em busca de um registro da história sobre a qual, até então, apenas os outros falaram, a quem não fora outorgada a função de autor de seus próprios textos.

Essas reflexões sobre a tradição do testimonio podem ser atualizadas de forma precisa e contundente nas proposições de Djamila Ribeiro (2019) sobre o lugar de fala. Com este conceito, a filósofa, que além de escritora é mulher e negra, nos apresenta vozes secularmente silenciadas pelas opressões de raça, gênero e classe e, assim, desnuda um sistema vigente que impossibilita narrativas.

Estudos recentes apontam para essa perspectiva do lugar de fala como um conceito capaz de abrir a história, de nos apresentar outra história. No artigo "Ensaiando lugares de escuta: diálogos entre a psicologia e o conceito de lugar de fala" (Gorjon, Mezzari, \& Basoli, 2019), as autoras enfatizam a relação do lugar de fala com a "escuta" como um conceito explorado pela psicologia e pela psicanálise que se mostra fundamental como exercício de alteridade. Em "De quem fala o lugar de fala?" (Name, 2020) e "O 'lugar de fala' e as 'falas do lugar' na enunciação literária: o dilema pós-colonial” (Mattos, 2021) é adensado o conceito aos estudos feministas e à literatura decolonial, perpassando os conflitos discursivos em torno da produção e da legitimação de saberes e de a quem se atribuem autoridade e credibilidade. Esse também é o caminho do artigo de Rayann de Carvalho (2020), que diz de um direito epistêmico comumente denegado àqueles e àquelas que sofrem com a violência, a exploração e a dominação de marca colonial. No artigo "'Lugar de fala': enunciação, subjetivação, resistência”, Mónica Fontana (2017) opera o lugar de fala para expor a crise acionada quando vozes historicamente silenciadas entram em cena. É uma profusão de pesquisas que se atêm a vozes que sofrem de história, nas quais o fato de tais vozes serem historicamente silenciadas não é sem efeito em como o que é dito é escutado ou legitimado no presente.

Nas reflexões sobre o testemunho, haverá uma construção ética sobre a lacuna que implica falar pelos outros, pois ou esses outros não estão mais aqui para falar, ou próprio ato de falar é corrompido pela dimensão traumática do referente. Já no caso do lugar de fala, esses outros falam por eles mesmos, falam justamente enquanto seu lugar de fala é reconhecido somente como Outro - o "estrangeiro", o "exótico", o "subalterno". Aqui, não vigora a necessidade de se medir a distância do ocorrido e o que isso implica nos índices de sua representabilidade; neste caso, dizer que o relato é precário ou que ultrapassa a imaginação parece corroborar com a violência que a construção teórica sobre o lugar de fala pretende denunciar.

O lugar de fala diz respeito à insurgência de uma voz que exige falar por si mesma - não mais que os outros falem por ela. Daí que Djamila Ribeiro assinala que se trata não de legitimar apenas a voz, como direito de falar, mas legitimar a história que é contada. A filósofa nos diz que para entender o lugar de fala é preciso ecoar a pensadora negra portuguesa Grada Kilomba (2019): "Quem pode falar? O que acontece quando nós falamos? Sobre o que nos é permitido falar?" (Ribeiro, 2019, p. 77). Como certas identidades têm sido historicamente silenciadas e desautorizadas no sentido epistêmico, trata-se de localizar ou de temporalizar quem pode falar ou não, quais vozes são legitimadas e quais não são.

$*$

O lugar de fala de sujeitos subalternizados e o testemunho podem ser estudados como teorias da memória na medida em que avaliam e buscam dar visibilidade ao peso dos tempos na possibilidade de enunciar o próprio tempo: possibilidade de uns e impossibilidade de outros. Nessa aproximação, no caso do lugar de fala, seria possível pensar em uma "testemunha integral". Os lugares de fala são hierarquizados: os que estão no topo podem falar, os que estão embaixo não 
podem. Então há certos lugares violentados cotidianamente por seu silenciamento, a partir dessa hierarquia. Aqui há sim o relato daqueles que fitam a górgona, quando isso significa deslegitimação/paralisação da palavra sempre a cada dia. Além disso, aqui nem sempre há um escudo de Perseu, mas antes as sobrevivências da imagem da escrava Anastácia.

Anastácia, cujo nome africano é desconhecido, foi uma mulher escravizada cuja imagem nos vem hoje sob a forma de um busto de mulher negra com uma máscara de tortura que lhe tampona a boca - impedindo-a de comer e de falar. No entanto a máscara de Anastácia não é uma imagem definitiva sobre o lugar de fala da mulher negra, segundo a articulação proposta por Djamila Ribeiro. Denota, sim, o difícil estado de tempo, ou seja, a provação que certos lugares de fala precisam atravessar para fazer-se ouvir e existir. E é "a máscara" que dá nome ao primeiro capítulo em livro da pensadora negra Grada Kilomba (2019) sobre memória do racismo cotidiano. A autora nos mostra a lembrança de ter ouvido falar muitas vezes dessa máscara em sua infância, o que a coloca a recontar essa história da máscara do silenciamento, remontando-a no presente assombrado por ela.

A escritora negra Conceição Evaristo nos lembra dessa imagem ao falar de uma insistência da palavra apesar da máscara. Djamila Ribeiro utiliza o seguinte comentário de Conceição Evaristo sobre essa imagem: "a gente fala pelos orifícios da máscara e às vezes a gente fala com tanta potência que a máscara é estilhaçada. E eu acho que o estilhaçamento é um símbolo nosso, porque nossa fala força a máscara" (Evaristo citado por Ribeiro, p. 76).

Lugar de fala, apesar de tudo. Como aponta Djamila Ribeiro (2019), todos temos lugar de fala. O que a pensadora faz é afirmar o lugar de fala que sempre foi silenciado na história como um lugar de fala legítimo dos negros e, principalmente, das mulheres negras. Esses lugares de fala podem dizer respeito também a uma aporia, caracterizados pela descaracterização e pelo silenciamento. Porém, enquanto as pensadoras apresentam esse diagnóstico, elas também o refutam, no sentido de não corroborar com o que se quer combater, funcionando elas mesmas como a própria prova de um estilhaçamento da difícil possibilidade dos deslocamentos dos lugares de fala. Por isso, apontam para um uso criativo do lugar de fala a fim de construir saídas emancipatórias.

É nesse sentido que Djamila Ribeiro nos lembra, nas primeiras páginas de seu livro, a respeito da pensadora feminista negra Lélia Gonzalez, em artigo publicado em 1984, intitulado "Racismo e sexismo na cultura brasileira", sobre a questão de a linguagem dominante ser usada como forma de manutenção de poder e deslegitimação da palavra. Lélia Gonzalez discorre sobre as pessoas cuja forma da fala destoa da forma culta. Diante do desdém e condescendência (diante de quem fala "Framengo" em vez de Flamengo, por exemplo), nomeou como "pretuguês" a valorização da linguagem falada pelos povos negros africanos escravizados no Brasil, na qual sobrevive a marca linguística de um idioma africano ao qual o $\mathrm{L}$ inexiste.

Notamos, assim, um ato de criação que atualiza um lastro temporal ocupando uma realidade dada como pronta, uma língua dada como pronta - outra legibilidade para a imagem da máscara. Uma legitimidade do passado que o presente do conceito de lugar de fala permite ler; daí que não seria somente uma legitimidade, mas também uma legibilidade: permite ler um difícil estado do tempo.

A assinatura do desastre não coloca apenas um problema dos índices de representabilidade do ocorrido ou se o passado é imaginável; neste, seria preciso interromper para perguntar: mas de que lugar de fala a história está sendo contada?

\section{$*$}

Talvez algo que possa confluir essas tendências epistemológicas sobre as vozes do desastre seja vir a pensá-las em sua dimensão de prova e de provação como forma de habitar as aporias. "Revelar a verdade sem ter como" (Brito, 2013, p. 70) ou falar sem ter como. Isso nos faz saltar a outra noção de testemunho implicada nas reflexões sobre a vez dos leitores e que encontra uma ressalva, ou melhor, resistências semelhantes às apontadas pela questão do lugar de fala.

Essa outra noção de testemunho, que não é bem uma nova noção, mas a outra face presente naquelas duas tradições mencionadas, é condição a todo testemunho. Anna Basevi (2013), em artigo sobre a literatura como uma forma de habitar as aporias do testemunho, nos aponta para a importância em ampliar tal conceito.

É um conceito proposto por Jeanne Marie Gagnebin, e que diz respeito ao testemunho como "aquele que não levanta da mesa" ou "aquele que não vai embora". Essas expressões são decantadas de um sonho muito comentado de Primo Levi (1988) descrito em $E$ isto um homem?, que ele conta ser um tipo de sonho recorrente no campo. Nesse sonho, ao retornar para casa com a felicidade intensa de contar aos próximos o horror já passado e ainda vivo o autor de repente percebe, com desespero, que ninguém o escuta, que os ouvintes se levantam e vão embora indiferentes. Uma ameaça faz que os ouvintes se retirem da mesa, no sonho de Levi, e é a do desterro e do impossível da narrativa. Gagnebin (2014) comenta que os ouvintes "vão embora, não querem saber, não querem permitir que essa história, ofegante, sempre ameaçada por sua própria impossibilidade, os alcance, ameace, também, sua linguagem ainda tranquila" (p. 57). A filósofa congela essa cena para nos falar de uma perspectiva de testemunho. Aqui, ela nos apresenta uma leitura que diz que "testemunha também seria aquele que não vai embora" (p. 57).

No caso do lugar de fala, essa cena pode ser aproximada de quando Grada Kilomba (2019) nos fala sobre ser necessário, por parte de quem sempre foi autorizado a falar, escutar. 
A filósofa fala de um medo branco que diz respeito a manter-se inconsciente como proteção diante de verdades e realidades advindas do conhecimento dos "Outros" - os que estão fora ou minorizados no circuito de poder que confere legitimidade e realidade ao que é dito. Seguindo a exposição de Djamila Ribeiro (2019) pela leitura de Grada Kilomba (2019), a dificuldade da pessoa branca em ouvir ocorre porque ela é confrontada com segredos coletivos (segredos como a escravidão, o colonialismo, o racismo) "e verdades desagradáveis da 'história muito suja'; assim, os sujeitos brancos argumentam não saber, não conhecer, não lembrar, não acreditar ou não ter sido convencido" (Ribeiro, 2019, pp. 78-79). Esses são movimentos de manutenção de seu lugar de fala ainda tranquilo.

Por esses estudos é desvelado que a dificuldade de escuta advém de uma possível consciência e, até mesmo, de uma suposta culpa pelo que está sendo relatado. Trata-se de uma leitura que também implica o leitor e o enreda no próprio acontecimento, como um cúmplice. Enredado ele aparece diante de si mesmo nas dobraduras da narrativa testemunhal, e ele, o leitor, aparece como um criminoso, como um dos possíveis carrascos, como ignóbil do qual ele mesmo pode nutrir vergonha. A narrativa seria como a distensão de um lençol do tempo e, nessa distensão, nesse lençol estendido como uma espécie de mesa, aparece a figura daquele que escuta como um dos protagonistas silenciosos do crime moral da infâmia. Ou até do crime, em seu sentido estrito de matar os sacrificáveis.

O romance Noturno do Chile, de Roberto Bolaño (2004), relata as memórias de um padre no tempo histórico correspondente ao Chile dos desaparecimentos, das perseguições, das prisões em massa. Em dado momento do livro, em uma espécie de sarau de artistas e intelectuais, uma personagem bêbada vagueia em corredores à procura de um banheiro, sai à procura de alívio, desce escadas, acidentalmente atravessa portas e corredores, que são como uma bruma, até abrir uma porta em que flagra o torturado em uma cama metálica, de olhos vendados, em um porão abaixo do encontro onde os convivas alegremente discutem sobre literatura e frivolidades.

Para Brito (2013), que evoca essa cena para pensar o trabalho de leitura do testemunho, "ler o testemunho é atravessar a bruma para encontrar na cama a vítima" (p. 76). Bruma de paralisia e urgência. $\mathrm{Na}$ insurgência da fala dos lugares de fala cuja boca é amordaçada pela hierarquia da legitimidade das vozes, essa tortuosa travessia diz respeito à exigência ética do trabalho de imaginar (que, ao mesmo tempo, coloca-se como ouvir) o estilhaçamento, apesar da máscara. A relação entre ler o testemunho e reconhecer esses lugares de fala tem a ver com o difícil estado de tempo dessas experiências, ou seja, uma memória que, para poder ser legível, no sentido de visível e de compreensível, a prova não vem descolada da provação. Por isso, captar tais vozes como inapropriadas ou agressivas é um sintoma do passado que elas ecoam, é fechar os olhos para a provação que faz com que se negue a prova (que, no caso, pode ser entendida como o próprio lugar da voz como inapropriado ou agressivo). Silêncio e invisibilidade de "sujeitos considerados implícitos dentro de certa normatização hegemônica" (Ribeiro, 2019, p. 43) que, ao falar, encontram ouvintes que, simplesmente, levantam-se da mesa. Levantam-se da mesa de montagem, pois montagem é uma operação de legibilidade. Assim, reiteramos que a vez dos leitores implica em permanecer na mesa e tomá-la como mesa de montagem.

\section{De semelhança a semelhança: ler e emancipar imagens do desastre}

A chegada da vez dos leitores envolve não ir embora, mas também atravessar a bruma e, em outras palavras, manejar o escudo: ler o que não foi escrito na imagem de Anastácia - imaginar: compor a provação da prova. No manejo do escudo de Perseu, há, na verdade, um desvio, para olhar diretamente para o monstro que transforma em pedra os homens que o encaram. Assim, manejar o escudo soma-se a uma argumentação do desvio do olhar naquilo que referimos como "abrir os olhos para a história". De um olhar reto e ostentatório, inquiridor como o de um juiz, para outro tipo, meio torto, artificioso, errante, infantil, clivado. Trata-se de uma estratégia do leitor para suportar as vidências que podem abatê-lo e matá-lo pelo teor do que revelam e pelo choque que provocam. Um desvio para demorar-se mais, para a paciência infinita diante do que está por vir e nunca chega por inteiro, mas aos poucos, desde que haja abertura para chegar e dar-se a ver e ouvir.

Não ir embora, atravessar a bruma, manejar o escudo, localizar os lugares de fala: verbos ativos que falam de uma tomada de posição diante do tempo e das imagens, ou do tempo inesgotável das imagens. Uma posição de criança montadora de legos - buscando o possível no inextrincável do fragmento - equivaleria a uma posição de leitor da violência inaudita em movimento ativo de imaginação sobre a legibilidade da história. Pois a história não está lá de modo a colhermos tal como foi; o conhecimento histórico não é um ato de deslocamento ao passado para descrevê-lo e colhê-lo "tal qual em si mesmo". Em suas teses sobre o conceito de história, Benjamin (2012) já nos dizia que o conhecimento histórico só acontece a partir do "agora", isto é, de um estado de nossa experiência presente de onde emerge.

Quando pensamos na imagem no domínio da história, vemos, com Benjamin (2006), que toda imagem carrega um índex histórico. Para o filósofo alemão, esse índex histórico não indica somente que as imagens pertenceram a uma determinada época; indica, sobretudo, que elas alcançam a legibilidade somente em uma época determinada. E o fato de as imagens alcançarem a legibilidade somente em determinada época representa determinado ponto crítico do movimento que 
as anima. Esse ponto crítico é um momento de memória e de legibilidade - uma vez, uma chance - que, até então, oferecia ao passado seu quadro mais ou menos reconhecível. Didi-Huberman (2018b) assevera que esse ponto crítico é chamado, por Benjamin, de imagem.

Por isso, ler o desastre coloca um desafio ético diante do presente tocando nesse pensamento do que a imaginação e a imagem podem fazer pela história.

Quando falamos em uma posição de semelhança do autor e do leitor é no sentido de uma produção do presente na forma de um coengendramento dessas duas figuras diante do inimaginável e do inaudito. Trata-se de uma ética sobre ler o desastre que também toca em uma ética de olhar as imagens que, segundo Didi-Huberman, como já dito, deve ter em conta uma situação permanentemente clivada. Por que "clivada"? Aqui, o pensador está operando o conceito de imagem dialética proposto por Benjamin. Dialética como aquela que não busca uma síntese ou resolução, mas que coloca em permanente conflito e paradoxo; Benjamin fala de uma "dialética em repouso" - ou seja, essa clivagem manteria as partes em repouso impedindo que os elementos sejam unificados, assimilados ou resolvidos. Nesse sentido, a imagem não ressuscita o passado; quando muito, recita, apesar do pouco que pode, a memória dos tempos. Por isso, em Didi-Huberman, a imagem não é uma coisa, ela é um ato. É um ato de imaginação que coloca sempre em jogo o que vemos e o que nos olha, ou podemos pensar no movimento de prova e provação da memória da catástrofe. "É preciso, diante de cada imagem, perguntar-se como ela (nos) olha, como ela (nos) pensa e como ela (nos) toca ao mesmo tempo" (Didi-Huberman, 2018a, p. 85).

$\mathrm{Na}$ imagem se desdobra a energia de Perseu, no sentido de uma "coragem de conhecer" (Didi-Huberman, 2012, p. 224), que seria a coragem de "incorporar na nossa memória um saber que, uma vez reconhecido, suprime um tabu que o horror, sempre paralisante, continua a fazer pesar sobre a nossa inteligência da história". Tomar imagens do desastre como imagens dialéticas equivale à exigência de um perigoso trabalho sobre os índices de legibilidade do mesmo:

não cessar de arregalar nossos olhos de crianças diante da imagem (aceitar a provação, o não saber, o perigo da imagem, a falha da linguagem) e não cessar de construir, como adultos, a "conhecibilidade" da imagem (o que supõe o saber, o ponto de vista, o ato de escritura, a reflexão ética). (Didi-Huberman, 2018b, p. 70)

A semelhança a que nos remontamos em diversos pontos desse texto atende a uma desconjunção ou a essa situação permanentemente clivada, na medida em que pensamos em semelhança como o interminável. DidiHuberman explora essa noção em artigo dedicado a pensar a imagem em Blanchot, mostrando como este procurou na imagem e na semelhança a experiência da literatura e, inclusive, como o conceito de imagem se dispõe ao conceito de espaço literário. O título desse artigo do historiador da arte é "De semelhança a semelhança". Nele, teremos a elaboração de uma semelhança que não se atém à repetição de um mesmo, mas arrasta a diferenciação infinita deste; isso que nos permite pensar a semelhança como desconjunção. Para Blanchot (2010), o mundo das semelhanças é vasto como a noite, porque nunca se consegue acabar com uma semelhança: "se o reino da imagem pode ser dito vasto como a noite, é, portanto, sobretudo em razão desta perpétua remissão - ruminantede semelhança a semelhança" (Didi-Huberman, 2011, p. 31).

Didi-Huberman lê essas palavras como a convocatória para compreender a imagem como uma modificação fundamental da temporalidade. Não trata o passado de modo que este explique o presente, mas, antes, o que está em questão é modo como o agora encontra o outrora para formar uma constelação de sentido. Assim como na dialética que Didi-Huberman apresenta a partir de Benjamin, para Blanchot a imagem é evidência tanto quanto enigma (Didi-Huberman, 2011). Portanto é um tempo que se coloca como enigma a ser recolhido e decifrado ao ser recitado.

Isso nos faz pensar em outro personagem de Roberto Bolaño (2016), desta vez do romance 2666: Almafitano, olhando a cidade através dos vidros, sentado no banco traseiro do carro, em um estado de quase sono, vê "imagens inapreensíveis, imagens que continham em si toda a orfandade do mundo" (p. 206). O que o escritor chileno faz aqui é solicitar que imaginemos, de modo insolúvel e interminável, o que seriam tais imagens. Elas contêm algo em si mesmas, mas algo que precisamos ficar olhando e imaginando por causa de sua estranha expressão "toda orfandade do mundo", que cabe somente em imagens que exigem um gesto de imaginar apesar de tudo.

Blanchot (citado por Didi-Huberman, 2017) fala de uma imagem que

não é mais a que nos permite manter o objeto ausente, mas a que nos pega pela própria ausência, ali onde a imagem, sempre à distância, sempre absolutamente próxima e absolutamente inacessível, escapa-nos, abre-se a um espaço neutro, no qual não podemos mais agir, e abre-nos, também a nós, a uma espécie de neutralidade na qual deixamos de ser nós mesmos e oscilamos estranhamente entre o Eu, Ele e ninguém. (p. 236)

\section{Conclusão}

Se permanecer à mesa depois do desastre seria tomá-la como mesa de montagem, então abrir os olhos para a história equivaleria a temporalizar as imagens que nos restam dela. Esse olhar comporta uma duração rascunhada nos conceitos da dialética da imagem. Aqui, queremos concluir dizendo que temporalizar as imagens tem a ver com emancipá-las. 
Emancipar - palavra tão política quanto cheia de história. Em uma breve genealogia explorada por Didi-Huberman (2018), aprendemos que emancipar vem do latim emancipare. Mancipare quer dizer "vender"; emancipare quer dizer liberar alguma coisa ou alguém de uma autoridade que, por sua vez, está ela própria ligada a um direito de propriedade, direito este adquirido por uma operação comercial, um ato de venda. "Uma imagem se vende e se compra, e isso é comum", diz o historiador da arte. Mas não se pode esquecer que, ao adquiri-la, seu proprietário adquire o direito de pendurá-la em sua sala (ou mesmo trancar a imagem em um cofre), assim como o de fazê-la desaparecer da esfera pública, da comunidade de espectadores.

Mancipas refere-se àquilo que pode ser vendido e comercializado (até pessoas quando são compradas como escravas).

Didi-Huberman escala dois aspectos das sobrevivências de emancipare para pensarmos em emancipar imagens. O primeiro é esse fundo de emancipar como deslocar o lugar de um valor de venda, ou seja, ler nas imagens algo de inestimável. Didi-Huberman fala de algo inestimável que faz sinal no presente em direção a uma questão colocada no passado. Nesse sentido, o filósofo nos fornece um exemplo do mundo do direito romano, no que se refere à prática da imago. A imago se refere aos bustos dos imperadores que podiam ser reproduzidos, mas não vendidos, podendo somente ser passados de geração em geração. A imago, pode-se dizer, era "ex-mancipata".
Um segundo aspecto assinala que emancipar reside na memória de que a palavra comercial mancipiun vem de manus, "mão", e de capere, "pegar". Aqui está $o$ aspecto ético de emancipar, pois pode-se fazer de melhor ou de pior com a mão; pode-se pegar um móbile para imobilizá-lo, um objeto para possuí-lo, ou uma pessoa para imobilizá-la e possuí-la ao mesmo tempo. Ou a outra via, o outro valor de uso de pegar com a mão, pois pode-se pegar um amigo, uma criança pela mão. "Mancipare é pegar com a mão alguma coisa - até mesmo alguém - que tornará sua propriedade privada. Emancipare seria pegar alguém pela mão para guiá-lo em direção a uma zona franca, um espaço de liberdade onde ele não será 'possuído' por ninguém" (DidiHuberman, 2018b, p. 143).

Emancipar as imagens é tomá-las por dialéticas, o que implica afirmar um inestimável sinal do presente em direção ao passado, articulando o tempo e o espaço de forma mutante. Pegar pela mão, ler, tomar posição de leitor para acompanhar, de semelhança em semelhança, até uma zona de possibilidades abertas.

Nossa hipótese, neste texto em que buscamos erguer a vez dos leitores, é que a leitura verdadeira do relato impossível do desastre só ocorrerá com a possibilidade do leitor de emancipar a imagem por meio de um trabalho (de imaginação apesar de tudo), buscando a semelhança, não a assimilação, do autor e do leitor. Fóssil em movimento. Mesa. Tempo que se compartilha sobre uma mesa e demorando-se à mesa.

\section{The reader's: the return of disaster}

Abstract: This paper discuss the issues surrounding the ethical role of creation and imagination in the face of disaster remains. We examine the theoretical articulations within the reflections on the concepts of Testimony and Standpoint, regarding the remembering or retelling the hard times. To this end, we identify aporetic creases in these concepts, which insist on exploring the place of reading and the reader before a paradoxical time that also stands as production and invention of the present time. We explore the possible articulations between time, imagination, image, catastrophe and responsibility, resulting in an ethical point of view broadened by the act of creation, which considers reading as a producer of memory.

Keywords: listening, memory, history, image; imagination.

\section{Le tour des lecteurs : le retour du désastre}

Résumé : Cet article aborde les questions relatives au rôle éthique de la création et de l'imagination face aux vestiges de catastrophes. Nous examinons les articulations théoriques au sein des réflexions sur les concepts de Témoignage et la Place de la Parole, concernant le souvenir ou le récit des moments difficiles. Pour cela, nous identifions des plis aporétiques dans ces concepts, qui insistent sur l'exploration de la place de la lecture et du lecteur devant un temps paradoxal qui tient aussi lieu de production et d'invention du temps présent. Nous explorons les articulations possibles entre le temps, l'imagination, l'image, la catastrophe et la responsabilité, entraînant l'élargissement d'un point de vue éthique à travers l'acte de création, qui considère la lecture comme productrice de mémoire.

Mots-clés : écoute, mémoire, histoire, image, imagination. 


\section{El turno de los lectores: el regreso del desastre}

Resumen: En este artículo planteamos el papel ético de la creación y la imaginación ante los restos del desastre. Pretendemos pasar las articulaciones teóricas que fundamentan las reflexiones sobre los conceptos de testimonio y de lugar de enunciación, poniéndolos en perspectiva en cuanto a volver a montar o volver a contar el tiempo sufrido. Para ello, ubicamos las arrugas aporéticas en estos conceptos, que insisten en la exploración del lugar de la lectura y del lector antes de un tiempo paradójico que también aparece como producción e invención de la actualidad. Exploramos el camino de las articulaciones entre tiempo, imaginación, imagen, catástrofe y responsabilidad, ocasionando la expansión de un punto de vista ético por el acto de creación, que sitúa a la lectura como la productora de memoria.

Palabras clave: escucha, memoria, historia, imagen, imaginación.

\section{Referências}

Agamben, G. (2013). O que resta de Auschwitz: o arquivo e a testemunha. São Paulo, SP: Boitempo.

Basevi, A. (2013). Silêncio e literatura: as aporias da testemunha. Alea, 15(1), 152-169. doi: 10.1590/S1517106X2013000100010

Benjamin, W. (2006). Passagens. Belo Horizonte, MG: Editora UFMG.

Benjamin, W. (2012). Obras escolhidas I: magia e técnica, arte e política (8a ed.). São Paulo, SP: Brasiliense.

Blanchot, M. (2010). A conversa infinita III: A ausência de livro. São Paulo, SP: Escuta.

Blanchot, M. (2011). O espaço literário. Rio de Janeiro, RJ: Rocco.

Bolaño, R. (2004). Noturno do Chile. São Paulo, SP: Companhia das Letras.

Bolaño, R. (2010). 2666. São Paulo, SP: Companhia das Letras.

Brito, A. B., Jr. (2013). A literatura e o local da diferença: entre testemunho e arquivo. Revista Landa, 2(1), 60-82. Recuperado de https://bit.ly/2TGAAgQ

Carvalho, R. K. M. (2020). Lugar de fala entre a experiência e a compreensão: Walter Mignolo, a localização do conhecimento e o direito epistêmico de falar em nome próprio. Revista Ciências do Estado, 5(2), 1-18. Recuperado de https://bit.ly/3y8APAf

Deleuze, G., \& Guattari, F. (2010). O que é a Filosofia? (3a ed.). São Paulo, SP: Editora 34.

Didi-Huberman, G. (2011). De semelhança a semelhança. Alea, 13(1), 26-51. doi: 10.1590/S1517-106X2011000100003

Didi-Huberman, G. (2012). Imagens apesar de tudo. Lisboa: Kymm.

Didi-Huberman, G. (2017). Quando as imagens tomam posição: o olho da história, I. Belo Horizonte, MG: Editora UFMG.

Didi-Huberman, G. (2018a). Atlas ou o gaio saber inquieto: o olho da história, III. Belo Horizonte, MG: Editora UFMG.

Didi-Huberman, G. (2018b). Remontagens do tempo sofrido: o olho da história, II. Belo Horizonte, MG: Editora UFMG.

Fonseca, T. M. G., Caimi, C. L., Costa, L. A., \& Sousa, E. L. A. (2018). Imagens do fora: um arquivo da loucura. Porto Alegre, RS: Editora Sulina.
Fonseca, T. M. G., Cardoso Filho, C. A., \& Resende, M. F. (2014). Testemunhos da infâmia: rumores do arquivo. Porto Alegre, RS: Editora Sulina.

Fontana, M. Z. (2017). "Lugar de fala": enunciação, subjetivação, resistência. Revista Conexão Letras, 12(18), 63-71. doi: 10.22456/2594-8962.79457

Gagnebin, J. M. (2014). Lembrar escrever esquecer. São Paulo, SP: Editora 34.

Gonzalez, L. (1984). Racismo e sexismo na cultura brasileira. Ciências Sociais Hoje, 223-244. Recuperado de https://bit.ly/3kZtS0E

Gorjon, M., Mezzari, D. C. S., Basoli, L. P. (2019). Ensayando lugares de escucha: diálogos entre la psicología y el concepto de lugar de habla. Quaderns de Psicologia, 21(1), 1-11. doi: 10.5565/rev/ qpsicologia. 1455

Kilomba, G. (2019). Memórias da plantação: episódios de racismo cotidiano. Rio de Janeiro, RJ: Cobogó.

Levi, P. (1988). É isto um homem? Rio de Janeiro, RJ: Rocco.

Levi, P. (1990). Os afogados e os sobreviventes. Rio de Janeiro, RJ: Paz e Terra.

Mattos, M. B. (2021). O "lugar de fala" e as "falas do lugar" na enunciação literária: o dilema pós-colonial. Literatura: Teoria, História e Crítica, 23(1), 161-184. Recuperado de https://bit.ly/3BHB6MN

Name, L. (2020). De que lugar fala o lugar de fala? Epistemologias do Sul, 4(1), 162-177. Recuperado de https://bit.ly/3f2DCDC

Oliveira, L. A. (2013). Quem fala por meio do testemunho? Alguns apontamentos teórico-metodológicos sobre a escrita testemunhal a partir da literatura de Primo Levi. Revista Latinoamericana de Metodología de la Investigacion Social, 3(5), 42-55. Recuperado de https://bit.ly/3f07dO4

Penna, C. (2013). Este corpo, esta dor, esta fome: notas sobre o testemunho hispano-americano. In M. Seligmann-Silva (Org.), História, memória, literatura. O testemunho na Era das Catástrofes (pp. 297-350). Campinas, SP: Editora da Unicamp.

Ribeiro, D. (2019). Lugar de fala. São Paulo, SP: Pólen. 
Scardino, R. (2013). A fala fora de lugar: testemunho, resto, tempo e linguagem em Ricardo Piglia. Alea: Estudos Neolatinos, 15(1), 170-183. Recuperado de https://bit.ly/3rC2RSd

Seligmann-Silva. (2008). Narrar o trauma: a questão dos testemunhos de catástrofes históricas. Psicologia Clínica, 20(1), 65-82. doi: 10.1590/S010356652008000100005
Seligmann-Silva, M. (2013). História, memória, literatura: o testemunho na Era das Catástrofes. Campinas, SP: Editora da Unicamp.

Recebido: 25/07/2019

Revisado: $12 / 07 / 2021$

Aprovado: 14/07/2021 